\title{
Penetration of Amitriptyline, but Not of Fluoxetine, into Brain is Enhanced in Mice with Blood-Brain Barrier Deficiency Due to Mdr1a P-Glycoprotein Gene Disruption
}

Manfred Uhr, M.D., Thomas Steckler, M.D., Alexander Yassouridis, Ph.D., and Florian Holsboer, M.D., Ph.D.

Mice with a genetic disruption (knockout) of the multiple drug resistance (Mdr1a) gene were used to examine the effect of the absence of the drug-transporting P-glycoprotein at the blood-brain barrier on the uptake of amitriptyline (AMI) and fluoxetine (FLU) and their metabolites into the brain. One hour after intraperitoneal injection of AMI or FLU, knockout (-/-) and wild-type (+/+) mice were sacrificed and drug concentrations of brain, kidney, liver, testis, and plasma were measured. The plasma concentrations of the AMI metabolites and the brain:spleen ratios of AMI, nortriptyline (NOR), 10-OH-AMI and 10$\mathrm{OH}-\mathrm{NOR}$ were significantly higher in the $-/-$ mice, demonstrating that AMI and its metabolites are substrates of the P-glycoprotein and that mdr1a activity at the level of the blood-brain barrier reduces the penetration of these substances into the brain. In contrast, tissue distributions of FLU and its metabolites among the various tissues tested were indistinguishable between groups. The herein reported differences in brain penetration of antidepressant drugs depending on the presence of the mdr1a gene may offer an explanation for differences in the treatment response at a given plasma concentration. Moreover, individual differences in mdr1 gene activity may account for variable response patterns at different episodes and development of therapy resistance. [Neuropsychopharmacology 22:380-387, 2000] (C) 2000 American College of Neuropsychopharmacology. Published by Elsevier Science Inc.
KEY WORDS: Amitriptyline; Fluoxetine; Multiple drug resistance gene; P-Glycoprotein; Mousemutants;

Therapy resistance

P-glycoprotein, a 170-kDa glycoprotein, is a member of a phylogenetically highly conserved superfamily of

From the Max Planck Institute of Psychiatry, Munich, Germany. Address correspondence to: Dr. Manfred Uhr, Max Planck Institute of Psychiatry, Kraepelinstrasse 10, D-80804 Munich, Germany.

Received May 24, 1999; revised August 9, 1999; accepted August 17,1999 .
ATP-binding cassette $(\mathrm{ABC})$ transport proteins (Higgins 1992; Doige and Ames 1993) that shares many features with numerous bacterial and eucaryotic $A B C$ transport proteins.

P-glycoprotein is encoded by the MDR1 gene in humans and the mdr1a (also called mdr3) and mdr1b (also called mdr1) gene in mice (Devault and Gros 1990). Although mdr1a and mdr1b are not always expressed in the same organs, the overall distribution of these genes in mice tissue coincides roughly with that of the single MDR1 gene in humans, suggesting that mdr1a and 
mdr1b together function in the same manner as human MDR1 (van de Vrie et al. 1998).

The MDR1 P-glycoprotein is a 1280 -amino acid glycosylated plasma membrane protein, consisting of two similar halves, each containing six putative transmembrane segments and one ATP binding site. It can actively transport its substrates against a concentration gradient, utilizing ATP hydrolysis as an energy source. The transported substrates for P-glycoprotein include anticancer drugs, such as anthracyclines, alkaloids, and other medically important drugs, such as the immunosuppressive agent cyclosporin A, the glycoside digoxin, the glucocorticoid dexamethasone (Meijer et al. 1998), local anesthetics, and the anthelmintic drug ivermectin (for review see Seelig 1998).

MDR1-type P-glycoprotein has been found in the apical membrane of the intestinal epithelial cells (Mukhopadhyay et al. 1988), in the biliary canalicular membrane of hepatocytes, and in the lumenal membrane of proximal tubular epithelial cells in the kidney (Thiebaut et al. 1987, 1989). High levels of MDR1 P-glycoprotein have been found in the lumenal membrane of the endothelial cells that line small blood capillaries and form the blood-brain and blood-testis barrier (Thiebaut et al. 1989; Cordon-Cardo et al. 1989, 1990; Tsuji et al. 1992). In addition, it has been demonstrated that P-glycoprotein found in the blood-brain barrier limits the brain accumulation of many drugs (Schinkel 1995a).

Using mdr1a knockout $(-/-)$ mice, we investigated whether certain antidepressants are substrates of the P-glycoprotein. We used mdr1a - / - and wild-type $(+/+)$ mice to study the role of P-glycoprotein in brain uptake of amitriptyline (AMI), a pharmacologically unspecific compound, and fluoxetine (FLU), a selective serotonin re-uptake inhibitor, and their metabolites. Mice lacking the mdr1a or mdr1b gene, or both, are healthy and fertile and devoid of abnormalities in anatomy, serum clinical chemistry, representation of lymphocyte classes, bile composition, and various other parameters (Schinkel et al. 1994, 1997).

\section{METHODS}

\section{Animals}

Male mdr1a - / - mice (FVB/NTac-[KO]Pgy1 N7) and $\mathrm{FVB}+/+$ mice, aged 12-15 weeks, bodyweight $29 \pm 3$ $\mathrm{g}$, were supplied by Taconic (Germantown, USA). Animals were housed individually and maintained at a 12:12 h light/dark cycle (lights on at 07:00 a.m.). The generation of the mutants has been described previously (Schinkel et al. 1994). Briefly, founder animals, originally generated on 129/Ola x FVB background, were backcrossed seven times (N7) into the FVB background. The colony is maintained at Taconic at N7 through intercrossing of homozygous mice.

\section{Experimental Procedures}

Five micrograms amitriptyline (AMI)/g mouse or 1.5 $\mu \mathrm{g}$ FLU/g mouse dissolved in $0.9 \%$ sodium chloride and $0.5 \%$ ethanol were administered intraperitoneally (i.p.). The entire volume injected was $10 \mu \mathrm{l} / \mathrm{g}$ mouse. One hour after injection, the mice were anesthetized with halothane and decapitated. Trunk blood was collected in EDTA-coated tubes and centrifuged at $3000 \mathrm{~g}$ for 5 min to determine the plasma concentration of the substances.

Cerebrum, metencephalon, liver, spleen, kidney, and testis were dissected and weighed and then homogenized in the fivefold volume of an HBSS, 0.02 M HEPES buffer, pH 7.2 with a polytron PT 1200 (Kinematic AG, Luzern, Switzerland). The homogenates were frozen at $-20^{\circ} \mathrm{C}$ until further use.

\section{Extraction Procedure}

After thawing, the samples were homogenized in a Branson sonifier. A total of $0.05 \mathrm{ml}$ of an internal standard solution (protriptyline $10 \mu \mathrm{g} / \mathrm{ml}$ ) and $0.4 \mathrm{ml}$ of 2 $\mathrm{M}$ sodium-carbonate buffer (adjusted to $\mathrm{pH} 10.5$ with $\mathrm{NaOH}$ ) were added to $0.4 \mathrm{ml}$ of plasma or homogenate and vortexed. Five milliliters n-hexan with various isoamyl alcohol concentrations were added and the samples were mixed for $30 \mathrm{~min}$ at room temperature.

A total of $0.6 \%$ respectively $3.5 \%$ isoamyl alcohol was used for the AMI and metabolite extraction from homogenates and 3.5\% isoamyl alcohol for the extraction from plasma. No alcohol was required for the FLU and norfluoxetine (N-FLU) extraction. After centrifugation for $15 \mathrm{~min}$ at $3000 \mathrm{~g}$ at room temperature, the organic layer was transferred to a tube containing $0.3 \mathrm{ml}$ $0.18 \mathrm{M}$ phosphoric acid, mixed for $30 \mathrm{~min}$ and centrifuged at $3000 \mathrm{~g}$ for $10 \mathrm{~min}$. The organic layer was then discarded, and a $60-\mu 1$ aliquot of the aqueous phase was injected for chromatographic separation.

\section{High-Performance Liquid Chromatography}

A Beckman 166 variable-wavelength UV fluorescence detector and a Merck L-7480 fluorescence detector, as well as a Beckman gradient pump 126 Solvent Module equipped with a Beckman autoinjector 507e autosampler were used for high-performance liquid chromatography analysis. Separations were made on a Luna $5 \mu$ C18(2) 250 x $4.6 \mathrm{~mm}$ column (Phenomenex, Torrance, USA).

The mobile phase A (acetonitrile-water, $43.6 \mathrm{mM}$ orthophosphoric acid, $35.9 \mathrm{mM}$ triethylamine (15:85)) and $\mathrm{B}$ (acetonitrile) were degased for $15 \mathrm{~min}$ in an ultrasonic bath immediately before use. The column temperature was $60^{\circ} \mathrm{C}$ and the flow of the mobile phase was $1.0 \mathrm{ml} /$ min. A 5-22\% mobile phase A gradient in $35 \mathrm{~min}$ and a $15-32 \%$ mobile phase A gradient in 20 min were used 
for chromatographic analysis of AMI and FLU and their respective metabolites. AMI and its metabolites were determined by UV absorption at 215 and $254 \mathrm{~nm}$, and FLU and N-FLU by UV absorption at $215 \mathrm{~nm}$ and fluorescence at $220 \mathrm{~nm}$ and $305 \mathrm{~nm}$, respectively.

\section{Quantification}

Plasma and organ samples were calibrated by using spiked samples at seven different concentrations. The concentrations ranged from 5 to $5000 \mathrm{ng} / \mathrm{ml}$ for AMI, nortriptyline (NOR), E- and Z-10-OH-AMI, as well as for E- and Z-10-OH-NOR, and from 1 to $1000 \mathrm{ng} / \mathrm{ml}$ for FLU and N-FLU. Quantification was performed by calculating the analyte:internal-standard peak-area ratio, and a straight-line regression model was fitted to the peak-area ratio of each compound to internal standard versus concentration.

\section{Materials}

AMI, NOR, E- and Z-10-OH-AMI, and E- and Z-10-OHNOR were gifts from Lundbeck (Copenhagen, Den- mark). Protriptyline, FLU, and N-FLU were purchased from RBI (Massachusetts, USA). All other chemicals were obtained in the purest grade available from Merck (Darmstadt, Germany).

\section{Statistical Analysis}

For each organ sample, the organ:spleen ratio was calculated and then the ratios for the mdr1a - / - and control mice were compared. Differences in the plasma concentrations of AMI and its metabolites, and of FLU and N-FLU between the mutants and the $+/+$ mice were tested for significance by one-factorial multivariate analyses of variance (MANOVAs). The plasma concentrations were the dependent variables and group, a between-subjects factor with two levels (mutants vs. $+/+$ mice) was the independent variable. One-factorial MANOVAs were also performed to test for significant differences between the two groups of mice in the concentration ratio for the various organ samples. When a significant group effect was found for an organ sample or plasma, univariate F-tests followed to identify the variables (ratios or concentrations), whose differences
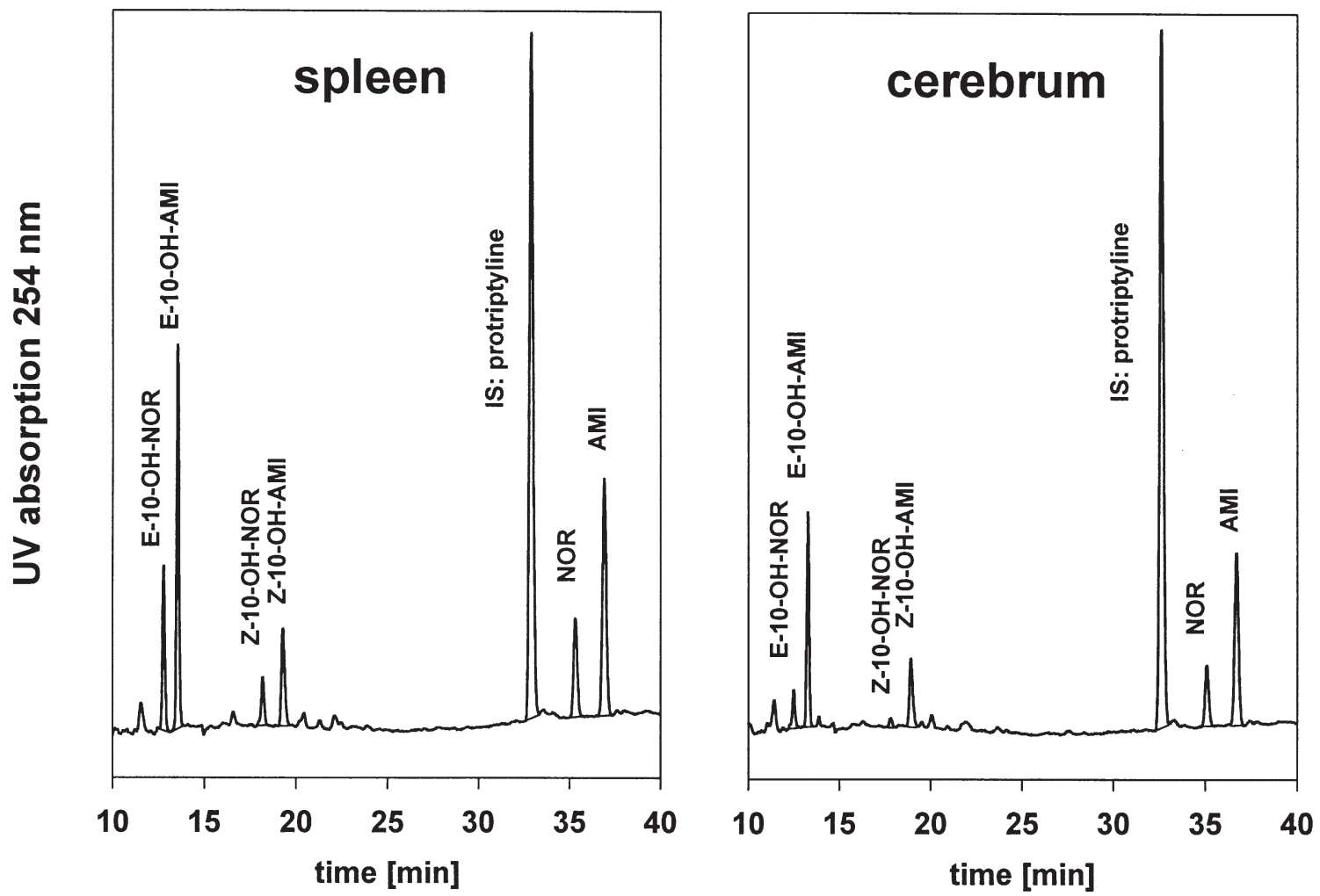

Figure 1. Representative chromatograms of mouse spleen and cerebrum extracts obtained one hour after i.p. injection of 5 $\mu \mathrm{g}$ AMI/g mouse. For the extraction procedure, sample extraction, and chromatography see Methods. The E-10-OH-NOR, E-10-OH-AMI, Z-10-OH-NOR, Z-10-OH-AMI, NOR, and AMI concentrations were 410, 825, 125, 285, 360, and 1015 ng/g spleen and 90, 440, 20, 175, 220, and $745 \mathrm{ng} / \mathrm{g}$ cerebrum, respectively. IS, internal standard solution. 

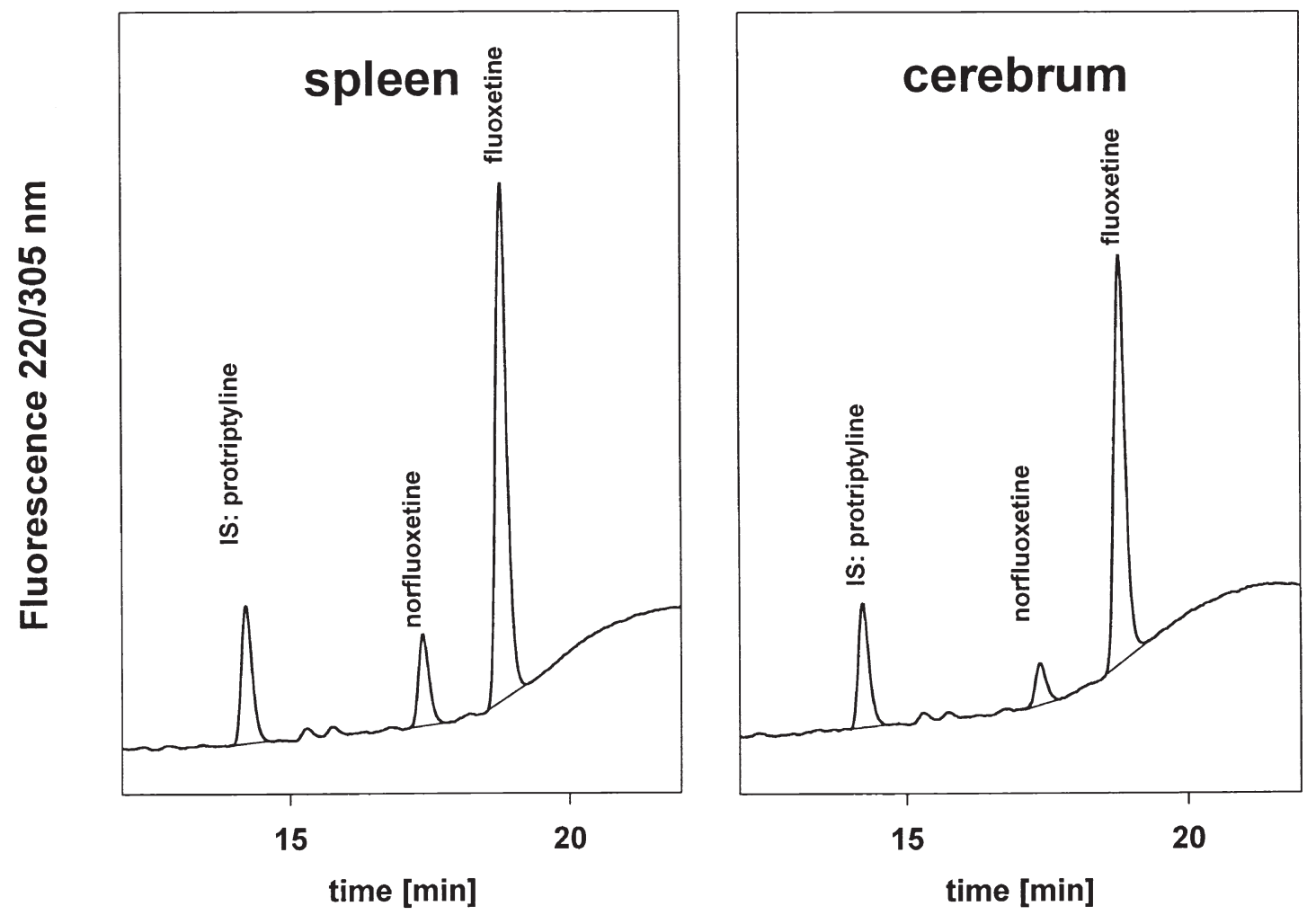

Figure 2. Representative chromatograms of mouse spleen and cerebrum extracts obtained one hour after i.p. injection of $1.5 \mu \mathrm{g} \mathrm{FLU/g}$ mouse. For the extraction procedure, sample extraction, and chromatography see Methods. The FLU and N-FLU concentrations were 2650 and $280 \mathrm{ng} / \mathrm{g}$ spleen and 128 and $1688 \mathrm{ng} / \mathrm{g}$ cerebrum, respectively. IS, internal standard solution.

between the two groups contributed significantly to the global group effect. As a nominal level of significance $\alpha=$ 0.05 was accepted and corrected (reduced according to the Bonferroni procedure) for all a posteriori tests (univariate F-tests) in order to keep the type I error less than or equal to 0.05 .

\section{RESULTS}

\section{Chromatography}

Representative chromatograms of the separations of AMI and its metabolites obtained from spleen and cerebrum extracts are shown in Figure 1. The plasma, cere-

Table 1. Plasma Concentrations of Amitriptyline and it Metabolites ( $\mathrm{n}=7$ for Both Mdr1a $-/-$ and Wild-Type Mice) as Well as Fluoxetine and Norfluoxetine ( $\mathrm{n}=6$ for Each Group) One Hour after i.p. Injection of $5 \mu \mathrm{g}$ AMI/g Mouse or 1.5 Fluoxetine/g Mouse

\begin{tabular}{|c|c|c|c|c|}
\hline \multirow[b]{2}{*}{$\begin{array}{l}\text { Substance } \\
{[\mathrm{ng} / \mathrm{ml}]}\end{array}$} & \multirow{2}{*}{$\frac{\text { mdr1a }-/-}{\text { Mean } \pm \text { SEM }}$} & \multirow{2}{*}{$\frac{\text { Mdr1a }+/+}{\text { Mean } \pm \text { SEM }}$} & \multirow[b]{2}{*}{ Ratio } & \multirow{2}{*}{$\begin{array}{c}\mathrm{p} \text {-values } \\
\text { Univariate } \\
\text { F-test in MANOVA }\end{array}$} \\
\hline & & & & \\
\hline AMI & $87.8 \pm 16.9$ & $89.1 \pm 12.3$ & 1.0 & n.s. \\
\hline NOR & $70.3 \pm 10.2$ & $25.8 \pm 2.7$ & 2.7 & $*$ \\
\hline E-10-OH-AMI & $66.7 \pm 9.5$ & $33.2 \pm 2.6$ & 2.0 & * \\
\hline Z-10-OH-AMI & $45.7 \pm 8.9$ & $12.7 \pm 2.2$ & 3.6 & * \\
\hline E-10-OH-NOR & $147.9 \pm 17.7$ & $52.9 \pm 5.1$ & 2.8 & * \\
\hline Z-10-OH-NOR & $178.8 \pm 30.2$ & $34.1 \pm 5.1$ & 5.2 & $*$ \\
\hline FLU & $107.8 \pm 9.5$ & $117.7 \pm 30.5$ & 0.9 & n.s. \\
\hline NFLU & $16.5 \pm 1.9$ & $14.1 \pm 3.5$ & 1.2 & n.s. \\
\hline
\end{tabular}

Values are mean \pm SEM.

*Significant difference $(p<.05)$; n.s. not significant. 

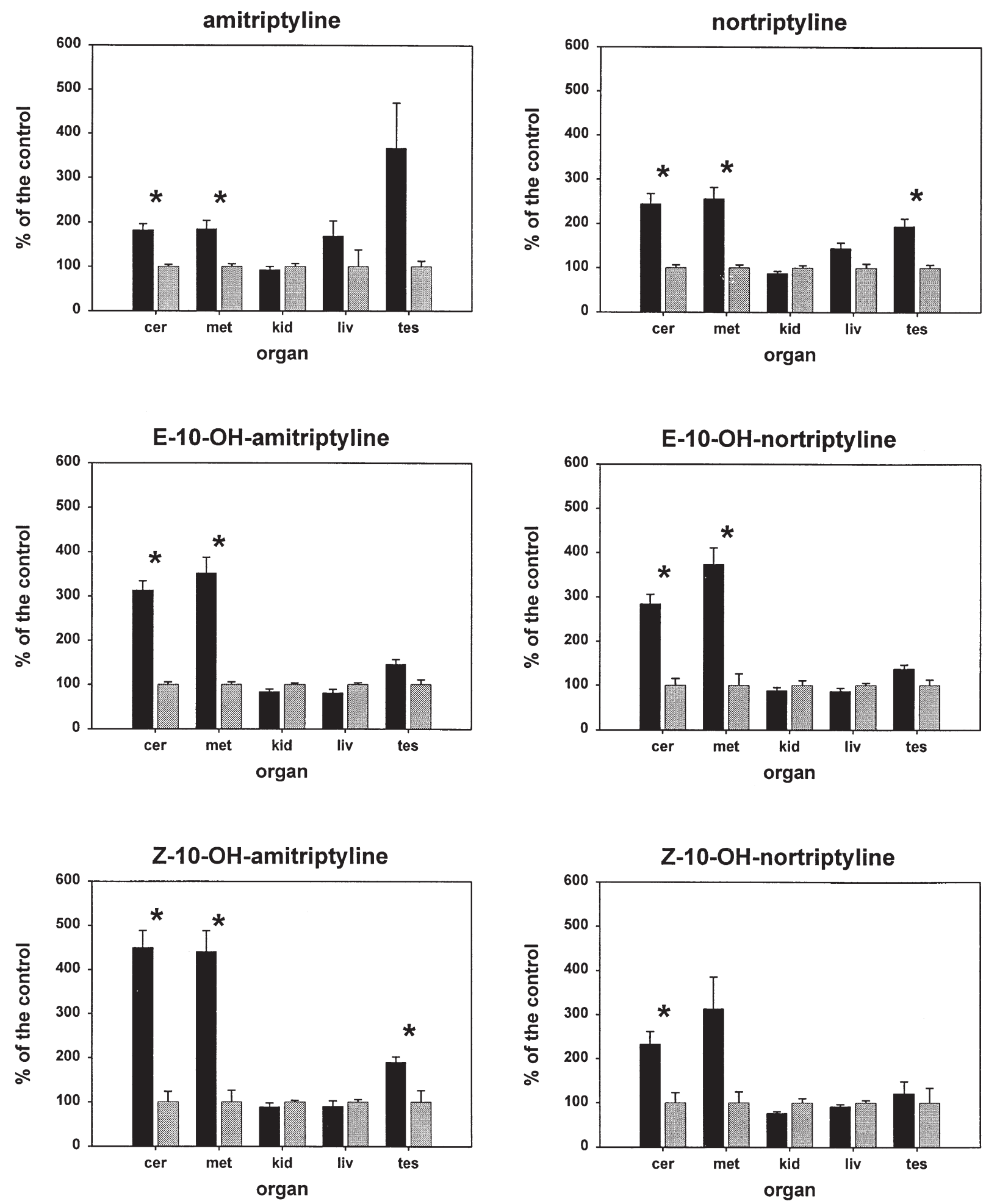

Figure 3. Organ:spleen ratios for amitriptyline and its metabolites in extracts obtained one hour after i.p. injection of $5 \mu \mathrm{g}$ $\mathrm{AMI} / \mathrm{g}$ mouse from mdr1a - / - mice (solid bars) and mdr1a +/ + control mice (shaded bars). The ratios are shown as percentage of the control. *indicate a significant difference between the $-/$ - mutants and the control mice (univariate F-tests in MANOVA, $p$-values < .05). Cerebrum (cer), metencephalon (met), kidney (kid), liver (liv), and testis (tes) were investigated. Values shown as means $\pm \operatorname{SEM}(n=7)$. 
brum, metencephalon, spleen, liver, and testis extraction recoveries, which were analyzed by comparing the peak heights of extracted standards with those of nonextracted standards, were in the range of $80-98 \%$ for AMI, NOR, E- and Z-10-OH-AMI, and E- and Z-10-OHNOR. Representative chromatograms of the separations of FLU and N-FLU are shown in Figure 2. For FLU and $\mathrm{N}-\mathrm{FLU}$, the extraction recoveries ranged from $78 \%$ to $99 \%$. The detection limits were $5 \mathrm{ng} / \mathrm{ml}$ for AMI, NOR, E- and Z-10-OH-AMI, as well as for E- and Z-10-OH$\mathrm{NOR}$, and $3.5 \mathrm{ng} / \mathrm{ml}$ for FLU and N-FLU.

\section{Plasma Concentrations of AMI, FLU and Their Metabolites}

Table 1 shows the plasma concentrations of AMI and its metabolites one hour after i.p. injection of $5 \mu \mathrm{g}$ AMI/g mouse. Analysis of variance revealed a significant group effect on the concentrations [Wilks multivariate test of significance; effect of group: $F(7,6)=4.85$; significance of $F=$ 0.036], to which reasonably only the concentrations of the metabolites NOR, E- and Z-10-OH-AMI, E- and Z-10-OHNOR contributed (univariate F-tests; $p$-values $<.05$ ). These values were significantly higher in the $-/-$ mice than in the controls. The $-/-:+/+$ ratio ranged between 2 and 5.2. Plasma concentrations of FLU and N-FLU, measured one hour after i.p. injection of $1.5 \mu \mathrm{g}$ FLU/g mouse, did not differ significantly between the two groups of mice (univariate F-tests; $p$-values < .05) (Table 1 ).

\section{Organ Concentrations of AMI, FLU and Their Metabolite}

Because the plasma concentrations of the AMI metabo- lites differed between the mdr1a $-/-$ mice and the controls, it is possible that this is due to differences in plasma pharmacokinetics between the two groups of mice. For this reason the organ to spleen ratios were calculated and compared. Figure 3 shows the organ:spleen ratios for AMI, NOR, E- and Z-10-OH-AMI, as well as E- and Z-10-OH-NOR as percentage of the control. MANOVA indicated significant group effects on the concentration ratios in cerebrum, metencephalon, and testis samples [Wilks multivariate test of significance; effect of group: $\min F(6,7)=4.81$; significance of $\mathrm{F}=$ 0.029].

The cerebrum:spleen ratio and the metencephalon:spleen ratio for AMI, NOR, E- and Z-10-OH-AMI, and E-10-OH-NOR were significantly higher in the mdr1a $-/-$ mice than in the mdrla $+/+$ controls (univariate F-tests, $p$-values $<.05$ ). The $-/-:+/+$ ratio ranged between 1.8 and 4.5. For Z-10-OH-NOR, only the cerebrum:spleen ratio was significantly increased. The testis:spleen ratio was significantly higher in the $-/-$ mice than in the control animals for $\mathrm{Z}-10-\mathrm{OH}-$ AMI and NOR (univariate F-tests; $p$-values $<.05$ ). Figure 4 shows the organ:spleen ratios for FLU and N-FLU as percentage of the control. There are no significant differences in the organ:spleen ratios between the two groups of mice.

\section{DISCUSSION}

The major finding of this study is that AMI and its metabolites penetrate into the brain more easily in the absence of the mdr1a gene product P-glycoprotein. This
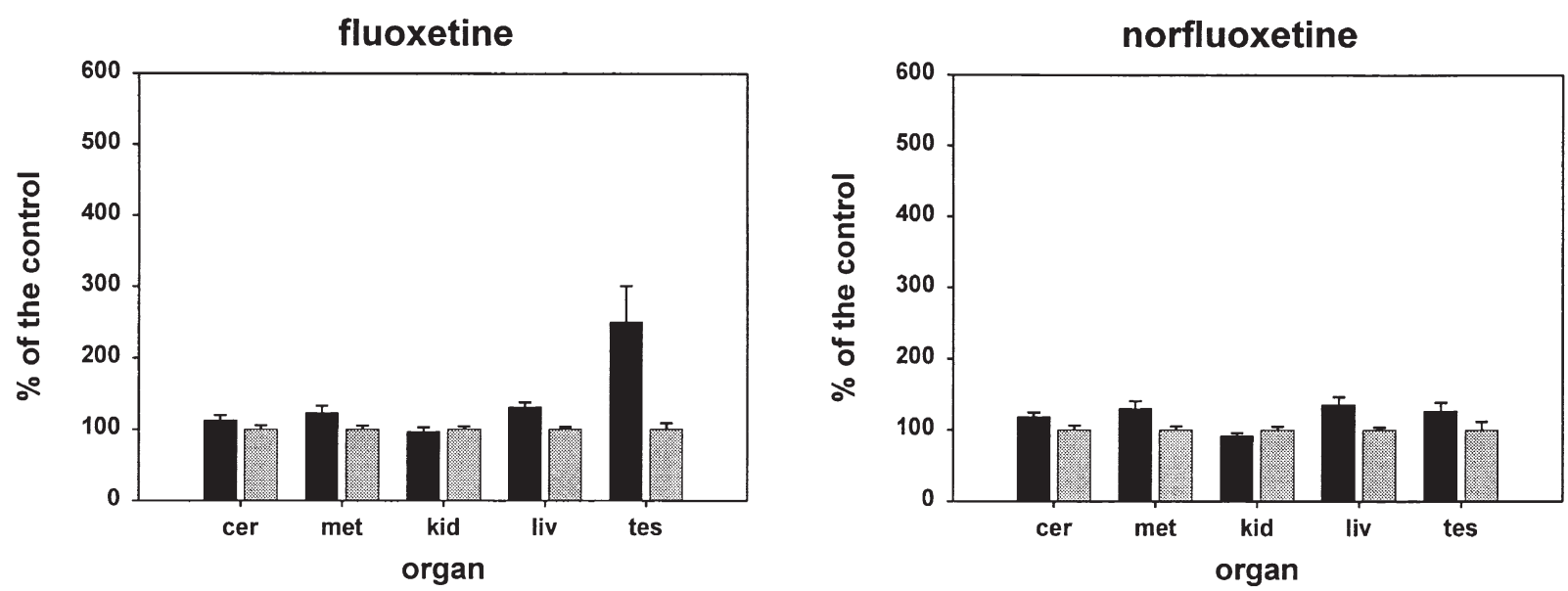

Figure 4. Organ:spleen ratios for FLU and N-FLU in extracts obtained one hour after i.p. injection of $1.5 \mu \mathrm{g}$ FLU/g mouse from mdr1a $-/-$ mice (solid bars) and mdr1a $+/+$ control mice (shaded bars). The ratios are shown as percentage of the control. *indicates a significant difference between the $-/-$ mutants and the $+/+$ control mice (univariate F-tests in MANOVA, $p$-values <.05). Cerebrum (cer), metencephalon (met), kidney (kid), liver (liv), and testis (tes) were investigated. Values shown as means $\pm \operatorname{SEM}(n=6)$. 
was demonstrated by a cerebrum:spleen ratio and a metencephalon:spleen ratio that was two to four times higher in mdrla $-/-$ mice than in $+/+$ control mice. It is very unlikely that the uptake of these substances into the spleen is influenced by P-glycoprotein because P-glycoprotein expression is low in this organ (Thiebaut et al. 1987; Cordon-Cardo et al. 1989, 1990), and in substrate distribution experiments only a few differences are recordable between the $+/+$ animals and the $-/-$ mutants (Schinkel et al. 1994, 1995b, 1996, 1997). Our results support the notion that the penetration of AMI and its metabolites into cerebrum and metencephalon is enhanced in mutants that lack P-glycoprotein, as compared to control mice, where P-glycoprotein is located in the endothelial cells of the brain capillaries. These findings indicate that AMI and its metabolites are substrates of P-glycoprotein. The mechanism underlying these differences appears to be an active retransport back into the circulation at the blood-brain barrier, mediated by the endothelial cells.

Using the blood-testis barrier as a reference, we found a similar effect, with penetration of Z-10-OHAMI and NOR into the testes being significantly higher in the mdrla $-/-$ mice than in the control animals.

The important role of P-glycoprotein is corroborated by our finding that uptake of AMI and its metabolites did not differ between the mutants and the controls in any organs in which P-glycoprotein is located, not in the endothelial cells of the organ investigated but in the tubules of excretory organs, e.g., the liver or the kidney. The tissue distribution of AMI and its metabolites in mdr1a $-/-$ and mdr1a $+/+$ mice is equivalent to that which has been described for other substrates of the same gene product (Schinkel et al. 1995b; Schinkel 1998; Tsuji and Tamai 1997).

The different plasma concentrations of the AMI metabolites in mutants and $+/+$ mice could have been caused by differences in the resorption of AMI from the peritoneum or by differences in the metabolization and elimination of AMI from the blood. The first-mentioned assumption is supported by the findings that after subcutaneous injection of AMI, the plasma concentrations of AMI and its metabolites did not differ between mdr1ab - / - mice and FVB control mice (data not shown). A reduced elimination of a number of intravenously administered substrates of P-glycoprotein has been observed in P-glycoprotein - / - mutants (Mayer et al. 1996; Borst and Schinkel 1997; Schinkel et al. 1997; Sparreboom et al. 1997).

A different situation was found after FLU administration. The plasma concentrations of FLU and N-FLU did not differ between the mdr1a $-/-$ and mdr1a $+/+$ mice, and there were no differences in the penetration of these substances into the different organs studied. Thus, the penetration of both compounds into the brain appears to be independent of the function of P-glyco- protein at the blood-brain barrier, which provides further evidence that penetration into brain is not generally impaired by the mdrla gene product.

This study demonstrates for the first time that a tricyclic antidepressant and its metabolites are substrates of P-glycoprotein. Therefore, the brain concentrations of AMI and its effective metabolites required for successful therapy with this drug are dependent on the function of the gene coding for P-glycoprotein and the activity of this protein as a pump transporting the antidepressant drug back into the brain microvessels.

The brain concentrations are dependent on the amount of bioavailable P-glycoprotein, which in turn depends on various factors. Certain substances inhibit the function of P-glycoprotein (Ford and Hait 1990), whereas others enhance its expression (Gottesman and Pastan 1993; Chin and Liu 1994). For this reason, plasma concentrations of the antidepressant do not allow a definite statement about the concentration in the brain. A patient with plasma concentrations of AMI and its metabolites in the normal range may in fact be receiving an insufficient dose because the penetration into the brain is reduced by an active retransport of the antidepressant drug through the P-glycoprotein located at the blood-brain barrier.

Whether expression of the mdr1a gene or the function of the P-glycoprotein itself is altered by antidepressants remains unanswered in this study, but is an interesting question in the context of refractory depression. It remains a clinical conundrum why patients who at one time responded to a certain drug do not respond when treated with the same drug for a later depressive episode. Perhaps, antidepressants or some of their derivatives alter expression patterns of mdr genes, which in turn may alter responsiveness in those antidepressants that are P-glycoprotein substrates. To test this hypothesis, long-term experiments with refined mouse mutant models and a large variety of structurally different antidepressants would be required.

To date, no structural characteristics required for being a substrate of P-glycoprotein have yet been identified, and it seems that no simple structure function relationship exists, which may explain the observation that patients who at one time did not respond to a certain compound may also be refractory to a different compound, regardless of pharmacology. Therefore, if a patient is refractory to a drug that is a P-glycoprotein substrate, it may make sense to switch to a substance whose brain penetration is unaffected by the P-glycoprotein. A yet-untested implication of therapy refractoriness is that there may be individual differences in blood-brain penetration of antidepressant drugs that remain undetected by analysis of plasma drug concentrations. We hypothesize that if a treatment trial in a patient with a drug that is a P-glycoprotein substrate has failed switching to a drug that is not a P-glycoprotein 
substrate may add to the list of options of the clinician dealing with therapy resistant patients.

\section{REFERENCES}

Borst P, Schinkel AH (1997): Genetic dissection of the function of mammalian P-glycoproteins. Trends Genet $13: 217-222$

Chin K, Liu B (1994): Regulation of the multidrug resistance (MDR1) gene expression. In Vivo 8:835-842

Cordon-Cardo C, O'Brien JP, Boccia J, Casals D, Bertino JR, Melamed MR (1990): Expression of the multidrug resistance gene product (P-glycoprotein) in human normal and tumor tissues. J Histochem Cytochem 38:1277-1287

Cordon-Cardo C, O'Brien JP, Casals D, Rittman-Grauer L, Biedler JL, Melamed MR, Bertino JR (1989): Multidrugresistance gene (P-glycoprotein) is expressed by endothelial cells at blood-brain barrier sites. Proc Natl Acad Sci USA 86:695-698

Devault A, Gros P (1990): Two members of the mouse mdr gene family confer multidrug resistance with overlapping but distinct drug specificities. Mol Cell Biol 10:1652-1663

Doige CA, Ames GF-L (1993): ATP-dependent transport systems in bacteria and humans: Relevance to cystic fibrosis and multidrug resistance. Annu Rev Microbiol 47:291-319

Ford J, Hait W (1990): Pharmacology of drugs that alter multidrug resistance in cancer. Pharmacol Rev 42:155-199

Gottesman MM, Pastan I (1993): Biochemistry of multidrug resistance mediated by the multidrug transporter. Annu Rev Biochem 62:385-427

Higgins CF (1992): ABC transporters: From microorganisms to man. Annu Rev Cell Biol 8:67-113

Mayer U, Wagenaar E, Beijnen JH, Smit JW, Meijer DKF, van Asperen J, Borst P, Schinkel AH (1996): Substantial excretion of digoxin via the intestinal mucosa and prevention of long-term digoxin accumulation in the brain by the mdr1a P-glycoprotein. Br J Cancer 119:1038-1044

Meijer OC, de Lange EC, Breimer DD, de Boer AG, Workel JO, de Kloet ER (1998): Penetration of dexamethasone into brain glucocorticoid targets is enhanced in mdr1A P-glycoprotein knockout mice. Endocrinology 139: 1789-1793

Mukhopadhyay T, Batsakis JG, Kuo MT (1988): Expression of the mdr (P-glycoprotein) gene in Chinese hamster digestive tracts. J Natl Cancer Inst 80:269-275

Schinkel AH (1998): Pharmacological insights from P-glycoprotein knockout mice. Int J Clin Pharmacol Ther 36: 9-13

Schinkel AH, Mayer U, Wagenaar E, Mol CAAM, van Deemter L, Smit JJM, van der Valk MA, Voordouw AC,
Spits H, van Tellingen O, Zijlmans JMJM, Fibbe WE, Borst P (1997): Normal viability and altered pharmacokinetics in mice lacking mdr1-type (drug-transporting) P-glycoproteins. Proc Natl Acad Sci USA 94:4028-4033

Schinkel AH, Mol CAAM, Wagenaar E, van Demeter L, Smit JJM, Borst P (1995a): Multidrug resistance and the role of P-glycoprotein knockout mice. Eur J Cancer 31A:1295-1298

Schinkel AH, Smit JJM, van Tellingen O, Beijnen JH, Wagenaar E, van Deemter L, Mol CAAM, van der Valk MA, Robanus-Maandag EC, te Riele HPJ, Berns AJM, Borst P (1994): Disruption of the mouse mdr1a P-glycoprotein gene leads to a deficiency in the blood-brain barrier and to increased sensitivity to drugs. Cell 77:491502

Schinkel AH, Wagenaar E, Mol CAAM, van Deemter L (1996): P-glycoprotein in the blood-brain barrier of mice influences the brain penetration and pharmacological activity of many drugs. J Clin Invest 97:2517-2524

Schinkel AH, Wagenaar E, van Deemter L, Mol, CAAM, Borst P (1995b): Absence of the mdr1a P-Glycoprotein in mice affects tissue distribution and pharmacokinetics of dexamethasone, digoxin, and cyclosporin A. J Clin Invest 96:1698-1705

Seelig A (1998): A general pattern for substrate recognition by P-glycoprotein. Eur J Biochem 251:252-261

Sparreboom A, van Asperen J, Mayer U, Schinkel AH, Smit JW, Meijer DKF, Borst P, Nooijen WJ, Beijnen JH, van Tellingen O (1997): Limited oral bioavailability and active epithelial excretion of paclitaxel (Taxol) caused by P-glycoprotein in the intestine. Proc Natl Acad Sci USA 94:2031-2035

Thiebaut F, Tsuruo T, Hamada H, Gottesman MM, Pastan I, Willingham MC (1989): Immunohistochemical localization in normal tissues of different epitopes in the multidrug transport protein P170: Evidence for localization in brain capillaries and crossreactivity of one antibody with a muscle protein. J Histochem Cytochem 37:159164

Thiebaut F, Tsuruo T, Hamada H, Gottesman MM, Pastan I, Willingham MC (1987): Cellular localization of the multidrug-resistance gene product P-glycoprotein in normal human tissues. Proc Natl Acad Sci USA 84:77357738

Tsuji A, Terasaki T, Takabatake Y, Tenda Y, Tamai I, Yamashima T, Moritani S, Tsuruo T, Yamashita J (1992): P-glycprotein as the drug efflux pump in primary cultured bovine brain capillary endothelial cells. Life Sci 51:1427-1437

Tsuji A, Tamai I (1997): Blood-brain barrier function of P-glycoprotein. Adv Drug Deliv Rev 25:287-298

van de Vrie W, Marquet RL, Stoter G, De Bruijn EA, Eggermont AM (1998): In vivo model systems in P-glycoprotein-mediated multidrug resistance. Crit Rev Clin Lab Sci 35:1-57 